\title{
Physicochemical and sensory properties of yogurt as affected by the incorporation of jumbo squid (Dosidicus gigas) powder
}

\author{
Javier S. Córdova-Ramos ${ }^{\mathrm{a}, \mathrm{b}, *}$, Ursula Gonzales-Barron ${ }^{\mathrm{c}}$, Luz M. Cerrón-Mallqui ${ }^{\mathrm{a}}$ \\ a School of Food Science, Department of Pharmacy and Pharmaceutical Administration, Faculty of Pharmacy and Biochemistry, Major National University of San Marcos, \\ Lima, Peru \\ ${ }^{\mathrm{b}}$ Faculty of Food Engineering, National Agricultural University La Molina, Lima, Peru \\ ${ }^{\mathrm{c}}$ CIMO Mountain Research Centre, School of Agriculture, Polytechnic Institute of Braganza, Braganza, Portugal
}

A R T I C L E I N F O

\section{Keywords:}

Jumbo squid flour

Sensory

Acidity

Syneresis

Viscosity

Quality

\begin{abstract}
A B S T R A C T
The increase of soluble solids in milk by the addition of powdered products is a normal practice in the elaboration of yogurt in order to enhance viscosity, texture and sensory properties for the consumer. The purpose of this study was to evaluate the effect of adding jumbo squid (Dosidicus gigas) powder (protein content, $420 \mathrm{~g} / \mathrm{kg}$ ) on the aforementioned quality properties of yogurt. Six formulations of yogurt were prepared with the addition of $0,1,3,5,7$ or $10 \mathrm{~g} / 100 \mathrm{~mL}$ jumbo squid powder, plus one formulation with $3 \mathrm{~g} / 100 \mathrm{~mL}$ maltodextrin. During fermentation, yogurts formulated with squid powder gradually achieved greater viscosity while producing both more acidity and at a higher rate than the controls. Apart from lower $\mathrm{pH}$ (hence, higher titratable acidity) and higher viscosity, the final enriched yogurts presented lower syneresis than the controls ( $\mathrm{p}<0.05$ ). Although the highest viscosity (58.90 Pa.s) and the lowest syneresis (1.00\%) was achieved by the yogurt with $10 \mathrm{~g} / 100 \mathrm{~mL}$ jumbo squid powder, it was the treatment formulated with $3 \mathrm{~g} / 100 \mathrm{~mL}(\mathrm{pH} 4.31$, acidity $0.85 \mathrm{~g} / 100 \mathrm{~g}$, viscosity 40.90 Pa.s and syneresis $9.10 \%$ ) that kept constant sensory properties, as evaluated by the panelists, while improving some physical properties of the control yogurts.
\end{abstract}

\section{Introduction}

Jumbo squid (Dosidicus gigas) is a hydro-biological resource abundant in the Peruvian sea which is, at present, directly consumed by the population (Alegre et al., 2014; Arkhipkin, Argüelles, Shcherbich, \& Yamashiro, 2014). As a commercial activity, the Peruvian fishing industry has undergone periods of crisis, which have had as main causes the overexploitation of this resource, underpinned by the lack of innovative competitiveness of companies in both the fishing and food industry sectors (Liu et al., 2013).

The rationale behind the realisation of this research work is the food problem of developing countries, such as Peru, where jumbo squid is generally available without added value (Alegre et al., 2014), which leads to a short shelf life, limited distribution and economic losses (Trübenbach et al., 2014). However, jumbo squid is considered one of the healthiest and most nutritious foods for its various functional properties, despite being seldom used in the food industry. Consequently, great interest has been generated in developing and improving food products by adding new products derived from jumbo squid, e.g. jumbo squid powder (Sant'Anna, Christiano, Marczak, Tessaro, \& Thys,
2014).

Yogurt is a food of mass consumption and perhaps the oldest of the healthy products that are on the market. Due to its various health benefits, much research has focused on developing new types of yogurts such as those fortified by the addition of fibers, vitamins, calcium and other nutrients from vegetable- or animal-origin foods (SantillánUrquiza, Méndez-Rojas, \& Vélez-Ruiz, 2017). In turn, the yogurt industries have diversified their products, improved their quality and enlarged their production (Martín-Sánchez, Navarro, Pérez-Álvarez, \& Kuri, 2009; Tahsiri, Niakousari, Khoshnoudi-Nia, \& Hosseini, 2017).

To improve technological properties of yogurt, such as syneresis and viscosity, new formulations and ingredients have been sought and tested (Dönmez, Mogol, \& Gökmen, 2017; Ozturkoglu-Budak, Akal, \& Yetisemiyen, 2016). For instance, due to the influence of the total milk solids on the consistency and aroma of yogurt, Cruz et al. (2013) determined the effect of the increase in total milk solids on the coagulation time of yogurt. They tested milk enrichment prior to fermentation by the addition of fructose, milk powder, and soy non-fatty solids, to a total solids value of about $14 \mathrm{~g} / 100 \mathrm{~g}$.

The effects of the addition of concentrated whey proteins and non-

\footnotetext{
* Corresponding author. Department of Pharmacy and Pharmaceutical Administration, School of Food Science, Faculty of Pharmacy and Biochemistry, University National Major of San Marcos, Jr. Puno $\mathrm{N}^{\circ} 1002$. Jardín Botánico, Lima 1, Peru.

E-mail address: jcordovar1@unmsm.edu.pe (J.S. Córdova-Ramos).
} 
fat solids in yogurt processing have also been tested (Brown, McManus, \& McMahon, 2012). Many investigations have been developed attempting the addition of solutes such as casein and hydrolyzed whey protein (Hashemi-Gahruie, Eskandari, Mesbahi, \& Hanifpour, 2015). Previous research (Osuna-Ruíz, Yepiz-Plascencia, Rouzaud-Sández, \& Ezquerra-Brauer, 2010; Rocha-Estrada, Córdova-Murueta, \& GarcíaCarreño, 2010) concluded that jumbo squid powder exhibits functional properties such as optimal solubility and easy incorporation into fluids. Such functional properties could be advantageous in the formulation of quality yogurts. Thus, in this context, the objective of this research study was to evaluate the effects of jumbo squid powder on the physicochemical properties of the enriched milk during fermentation; as well as on the final physicochemical and sensory properties of the product.

\section{Materials and methods}

\subsection{Milk and jumbo squid powder}

Ultra-high-temperature (UHT) (heat-treated at $135^{\circ} \mathrm{C}$ ) whole milk $(30.00 \mathrm{~g} / \mathrm{L}$ total protein, $31.25 \mathrm{~g} / \mathrm{L}$ total fat, $47.92 \mathrm{~g} / \mathrm{L}$ carbohydrates, in wet basis) was purchased from a commercial establishment. Commercial starter cultures (YoFlex-L702, Chr Hansen), which contained Streptococcus thermophilus and Lactobacillus delbrueckii ssp. bulgaricus was purchased from Montana (Lima, Peru). The jumbo squid was purchased at Callao Fishery Terminal. Jumbo squids were placed in trays covered with ice, and transported to the processing facilities (Callao Technologic Institute of Production, Peru). The muscle of the jumbo squid mantle was filleted into $5 \times 5 \times 1-\mathrm{cm}$ strips and they were washed in water in a dilution 1:3 (jumbo squid:water, w/w) with $5 \mathrm{~g} / \mathrm{kg}$ citric acid and $10 \mathrm{~g} / \mathrm{kg}$ sodium chloride dissolved (food grade). Then, the jumbo squid strips were taken to a chilling room at $4{ }^{\circ} \mathrm{C}$ for $4 \mathrm{~h}$; time after which the dilution was neutralized with $1 \mathrm{~g} / \mathrm{kg}$ sodium bicarbonate (food grade). Once neutralized, it was left for $4 \mathrm{~h}$ more in the same chilling room at $4{ }^{\circ} \mathrm{C}$. Subsequently, the strips were wet milled in a silent cutter (Horiba, Japan) for $8 \mathrm{~min}$, until obtaining a homogeneous fine paste. The obtained paste was diluted with ice water in a ratio of 1:1 (w/w). Subsequently, $200 \mathrm{~g} / \mathrm{kg}$ of maltodextrin (D.E. 11, Brand Aromas of Peru) was added to the paste, which, in turn, acted as an encapsulating agent. Finally, it was spray-dried (Spray Dried Model A81, Aromas of Peru), under operating conditions of $190^{\circ} \mathrm{C}$ inlet temperature and $1.3 \mathrm{~L} / \mathrm{min}$. The jumbo squid powder ( $\mathrm{pH} \mathrm{5.7)} \mathrm{used} \mathrm{in} \mathrm{this}$ work presented the following chemical composition: $419.7 \mathrm{~g} / \mathrm{kg}$ total protein, $20.6 \mathrm{~g} / \mathrm{kg}$ total lipids, $501.6 \mathrm{~g} / \mathrm{kg}$ carbohydrates, $48.6 \mathrm{~g} / \mathrm{kg}$ moisture and $9.5 \mathrm{~g} / \mathrm{kg}$ total minerals, in wet basis.

\subsection{Jumbo squid powder solubility essay}

One gram of powder was weighed, and stirred into $100 \mathrm{~mL}$ of distilled water at ambient temperature in a beaker. The solubility was determined at different rehydration temperatures: $21,35,45$ and $63^{\circ} \mathrm{C}$, which were selected by preliminary tests (Cano-Chauca, Stringheta, Ramos, \& Cal-Vidal, 2005). To maintain the temperature, the solutions were kept in a water bath throughout the measurement time. Rehydration times were set every $30 \mathrm{~min}$ until reaching $2 \mathrm{~h}$. Five $\mathrm{mL}$ were pipetted from the solution to determine total solids content per $\mathrm{g}$ solution (TS), which was determined by oven drying at $105^{\circ} \mathrm{C}$ for $5 \mathrm{~h}$. In addition, $10 \mathrm{~mL}$ solution was pipetted into essay tubes and centrifuged at $3000 \mathrm{rpm}$ for $5 \mathrm{~min}$. Then, $5 \mathrm{~mL}$ of the supernatant liquid was taken to quantify the soluble solids content per g solution (SS) following the above procedure. The solids recovered were weighed after drying and the solubilisation capacity (CS, non-dimensional) was calculated as SS divided by TS (Mimouni, Deeth, Whittaker, Gidley, \& Bhandari, 2009). For each combination of rehydration temperature and time, a mean value of solubilisation capacity was obtained by
$C S=\sqrt{\frac{\sum_{i=1}^{n}\left(C S_{i}\right)^{2}}{n}}$

where $n$ was 5 rehydration time points.

\subsection{Preparation of yogurt}

Jumbo squid powder was added to the UHT milk ( $5 \mathrm{~L}$ at $21^{\circ} \mathrm{C}$ ) at 1 , 3, 5, 7 and $10 \mathrm{~g} / 100 \mathrm{~mL}$ (YM1, YM3, YM5, YM7, and YM10), then these were heated at $63^{\circ} \mathrm{C}$ for $90 \mathrm{~min}$ with constant agitation to dissolve the powder in milk. These formulations plus the two controls: without jumbo squid powder (YM0) and with maltodextrin at $3 \mathrm{~g} / 100 \mathrm{~mL}$ (YMMalt3), were pasteurized (heat treated at $85^{\circ} \mathrm{C}$ for $10 \mathrm{~min}$ ) in a big container, cooled down to $42{ }^{\circ} \mathrm{C}$ inoculated with $0.002 \mathrm{~g} / 100 \mathrm{~mL}$ starter cultures (starter culture was propagated in flasks by reconstituting in $100 \mathrm{~mL}$ pasteurized milk), and then incubated in 10 beakers $(500 \mathrm{~mL})$ for $6 \mathrm{~h}$ at $42^{\circ} \mathrm{C}$. After incubation, the coagulated milk (yogurt) was cooled down to $10^{\circ} \mathrm{C}$ (Alfaro et al., 2015). Yogurts were produced in the laboratory. They were chill stored at $4{ }^{\circ} \mathrm{C}$ until the next day for analysis.

\subsection{Analyses of fermenting milk and yogurt}

During fermentation, samples of $500 \mathrm{~mL}$ milk (a beaker) were taken every hour to carry out measurements of $\mathrm{pH}$, acidity (acid-base titration) (AOAC, 2005), and viscosity using a rotational viscometer (Brookfield, DV-E, USA) with a helipath stand mounted with a T-C spindle that rotated at $100 \mathrm{rpm}$ in a $100 \mathrm{~mL}$ sample at $25^{\circ} \mathrm{C}$ (SantillánUrquiza et al., 2017). The same analyses were performed on the finished product (yogurt). Additionally, the yogurt's syneresis essay was performed by centrifugation at $4000 \mathrm{rpm}(1200 \mathrm{~g})$ for $15 \mathrm{~min}$ (Dönmez et al., 2017) using $10 \mathrm{~g}$ of sample at $4^{\circ} \mathrm{C}$. The percentage of syneresis was calculated as 100 times the supernatant weight divided by sample weight.

The sensory evaluation of yogurts was undertaken by means of the acceptability test and the ninth-grade hedonic scale (Sant'Anna et al., 2014). The seven samples were evaluated a day after preparation by 100 semi-trained panelists ( 50 male and 50 female, $20-25$ years old). During the assessment, each panelist qualified a sample on a nine-point scale where one represented the lowest intensity of liking and nine the highest intensity of liking (Sant'Anna et al., 2014), for the sensory properties of flavor, aroma, texture, and color, which were explained beforehand to the panelists.

\subsection{Statistical analysis}

All measurements described above were obtained in triplicate and the results are shown as average \pm standard deviation. One-way analysis of variance and Tukey's test analysis of means were employed to determine significant differences among treatments. Values were considered significant when $\mathrm{p}<0.05$. Statistical analysis was performed using the SPSS 18.0 statistical package program (SPSS Inc., Chicago, IL).

\section{Results and discussion}

\subsection{Solubility of jumbo squid powder}

According to Arias-Moscoso et al. (2014), soluble solids increase in pulverized and hydrolyzed products. In our experiment, at the highest tested temperature of $63^{\circ} \mathrm{C}$, the soluble solids of jumbo squid powder approached the mass fraction of total solids as exposure time increased (Fig. 1A). Dihort-García et al. (2016) explained that the solubility capacity is a functional property that most foods with high protein content present. The results obtained show that the solubilization capacity increases as the exposure time and temperature increase (Fig. 1B). The 

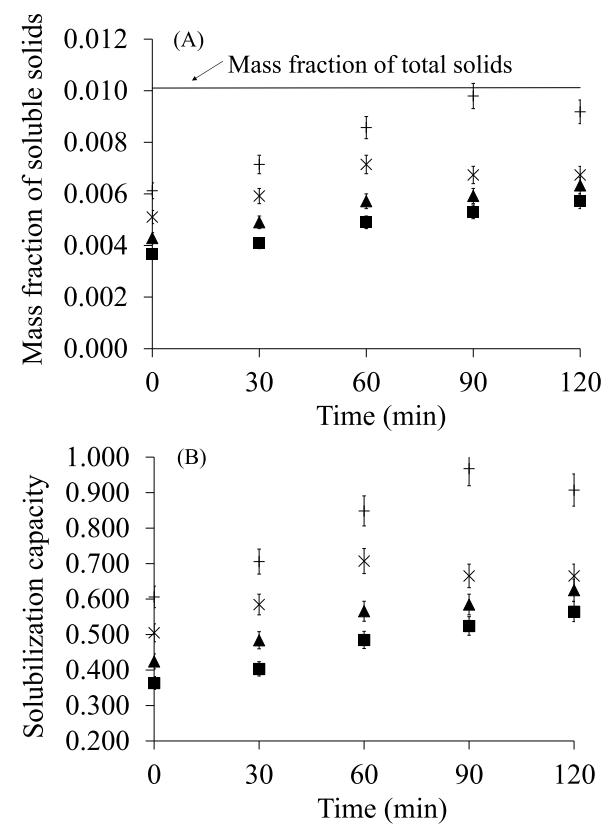

Figure 1. Solubility of jumbo squid powder in distilled water: (A) Evolution of mass fraction of total solids (horizontal line) and soluble solids at different temperatures; (B) Solubilization capacity as a function of time and temperature. Symbols: $21 ; \boldsymbol{3 5}$; $\times 45$ and $+63^{\circ} \mathrm{C}$.

maximum solubilization capacity achieved by the jumbo squid powder was 0.818 at $63^{\circ} \mathrm{C}$ after $90 \mathrm{~min}$ rehydration. In contrast, the solubilization capacity at room temperature after $90 \mathrm{~min}$ rehydration was lower at 0.530 . Temperature is a very important factor in the solubilization of jumbo squid powder; therefore $63{ }^{\circ} \mathrm{C}$ was used as solubilization temperature in the processing of yogurt enriched with this ingredient (Cano-Chauca et al., 2005; Dihort-García et al., 2016).

\subsection{Properties of fermenting milk}

The addition of jumbo squid powder notably affected the evolution of $\mathrm{pH}$ and titratable acidity in milk during incubation (Fig. 2A-B). In comparison to the control treatments (YM0 and YMMalt3), when jumbo squid powder was incorporated, the final $\mathrm{pH}$ achieved at the end of fermentation was lower.

The sole addition of jumbo squid powder ( $\mathrm{pH}$ 5.7) decreased the $\mathrm{pH}$ of milk, as can be observed in Fig. 2A where, at time 0 , the $\mathrm{pH}$ of the control (YM0) was higher (6.70) than those of the treatments with jumbo squid powder. In the control treatment (YM0), $\mathrm{pH}$ decreased up to 4.84 at $5 \mathrm{~h}$ and then stabilized until the $6 \mathrm{~h}$ of fermentation. Compared to the other treatments, the $\mathrm{pH}$ values were lower at each time interval, product of the effect of the new ingredient. It was interesting to notice that, at $3 \mathrm{~h}$ of fermentation, the $\mathrm{pH}$ values of the jumbo squid powder treatments did not differ among themselves (ranging between 4.8 and 5.0); yet, they were significantly lower than that reached by the controls (YM0 and YMMalt3) after the same incubation time (Fig. 2A). Earlier, Sant'Anna et al. (2014) and Tahsiri et al. (2017) showed that the incorporation of powders into formulations prompt a higher level of acidity during fermentation. On the one hand, this is due to the chemical composition of jumbo squid powder, and on the other hand, the production rates of lactic acid are increased as a result of the fermentation of more carbohydrates in the enriched medium by the lactic starter culture (Ale et al., 2016). Their primary function is the production of lactic acid from lactose; however, under conditions of excess glucose and limited use of oxygen, they transform $1 \mathrm{~mol}$ of glucose to lactic acid (Ozturkoglu-Budak et al., 2016). Whilst maltodextrin, a mixture of glucose polymers (Ako, 2015), is part of the chemical
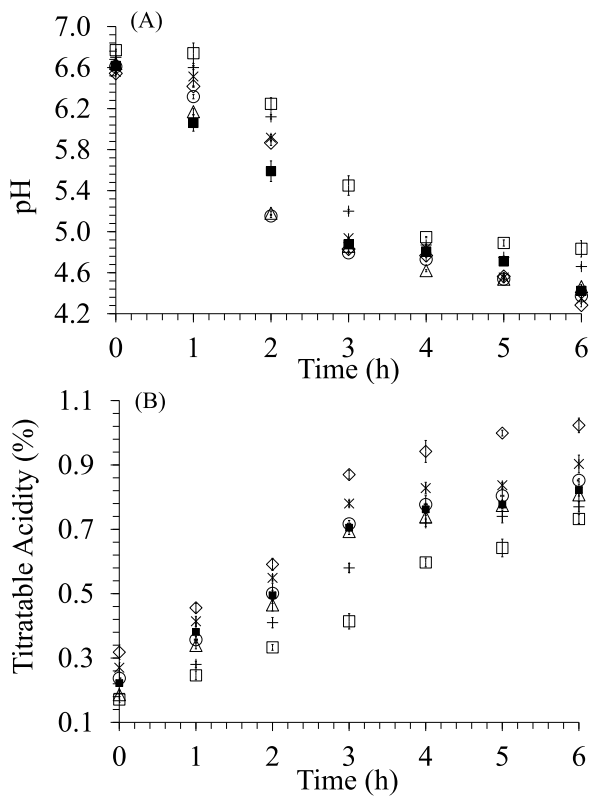

Figure 2. Decrease of $\mathrm{pH}$ (A) and increase in titratable acidity (B) during the fermentation period of yogurt produced with $1 \mathrm{~g} / 100 \mathrm{~mL}(\Delta \mathrm{YM} 1), 3 \mathrm{~g} / 100 \mathrm{~mL}$ (ם YM3), $5 \mathrm{~g} / 100 \mathrm{~mL}$ (O YM5), $7 \mathrm{~g} / 100 \mathrm{~mL}$ (* YM7), $10 \mathrm{~g} / 100 \mathrm{~mL}(\diamond \mathrm{YM} 10)$ ), no addition ( $\square$ YM0) of jumbo squid powder, and $3 \mathrm{~g} / 100 \mathrm{~mL}$ (+ YMMalt3) of maltodextrin. Values are means of three replicates experiments.

composition of jumbo squid powder, they are fermentable by lactic acid bacteria (Brown et al., 2012). Thus, it is likely that the metabolism of these polysaccharides by lactobacilli generated more lactic acid (i.e., lower $\mathrm{pH}$ ) in the jumbo squid powder formulations.

The titratable acidity increased as higher proportions of jumbo squid powder were added to the milk (Fig. 2B), and the values were higher than the controls (YM0 and YMMalt3). Acidity, like pH, is a very important property in dairy products because it is positively correlated with quality and preference (Saint-Eve, Lévy, Martin, \& Souchon, 2006; Santillán-Urquiza et al., 2017). In addition, it is also an indicator of microbial stability as high acidity retards the development of spoilage microorganisms that deteriorate milk during fermentation and beyond (Hashemi-Gahruie et al., 2015).

Viscosity (Fig. 3) is one of the most appreciated quality attributes of yogurt (Ako, 2015; Arango, Trujillo, \& Castillo, 2013). From the results, the yogurt's viscosity increased as the incubation time elapsed (Fig. 3). Moreover, the increase in viscosity during incubation depended on the total solids content and the jumbo squid protein effect present in the

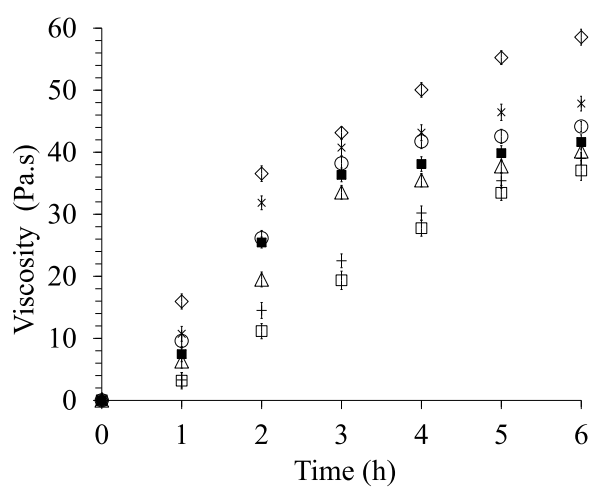

Figure 3. Increase in viscosity during the fermentation period of yogurt produced with $1 \mathrm{~g} / 100 \mathrm{~mL}$ ( $\Delta$ YM1), $3 \mathrm{~g} / 100 \mathrm{~mL}$ ( $\square$ YM3), $5 \mathrm{~g} / 100 \mathrm{~mL}$ (O YM5), $7 \mathrm{~g} / 100 \mathrm{~mL}(*$ YM7), $10 \mathrm{~g} / 100 \mathrm{~mL}(\diamond \mathrm{YM} 10)$ ), no addition ( $\square$ YM0) of jumbo squid powder, and $3 \mathrm{~g} / 100 \mathrm{~mL}$ ( + YMMalt3) of maltodextrin. Values are means of three replicates experiments. 
Table 1

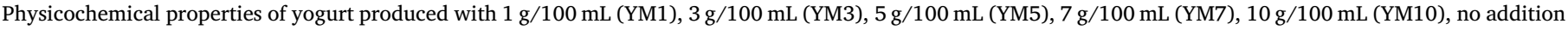
(YM0) of jumbo squid powder, and $3 \mathrm{~g} / 100 \mathrm{~mL}$ (YMMalt3) of maltodextrin (Mean value \pm standard deviation; $\mathrm{n}=3$ ).

\begin{tabular}{|c|c|c|c|c|}
\hline Treatments & $\mathrm{pH}$ & $\begin{array}{l}\text { Titratable Acidity } \\
(\%)\end{array}$ & Viscosity (Pa.s) & $\begin{array}{l}\text { Syneresis } \\
(\%)\end{array}$ \\
\hline YM1 & $4.43 \pm 0.006^{\mathrm{a}}$ & $0.81 \pm 0.009^{\mathrm{a}}$ & $38.66 \pm 0.360^{\mathrm{a}}$ & $10.4 \pm 0.020^{\mathrm{a}}$ \\
\hline YM3 & $4.31 \pm 0.006^{\mathrm{b}}$ & $0.85 \pm 0.005^{\mathrm{b}}$ & $40.93 \pm 0.290^{\mathrm{b}}$ & $9.10 \pm 0.010^{\mathrm{ab}}$ \\
\hline YM5 & $4.21 \pm 0.010^{c}$ & $0.89 \pm 0.005^{c}$ & $44.33 \pm 0.340^{c}$ & $7.50 \pm 0.020^{c}$ \\
\hline YM7 & $4.16 \pm 0.012^{\mathrm{cd}}$ & $0.94 \pm 0.010^{\mathrm{d}}$ & $48.03 \pm 0.350^{\mathrm{d}}$ & $4.20 \pm 0.020^{\mathrm{d}}$ \\
\hline YM10 & $4.06 \pm 0.008^{\mathrm{e}}$ & $1.05 \pm 0.011^{\mathrm{de}}$ & $58.90 \pm 0.250^{\mathrm{e}}$ & $1.00 \pm 0.010^{\mathrm{e}}$ \\
\hline YMO & $4.65 \pm 0.015^{\mathrm{f}}$ & $0.76 \pm 0.010^{\mathrm{f}}$ & $32.71 \pm 0.330^{f}$ & $16.1 \pm 0.090^{\mathrm{f}}$ \\
\hline YMMalt3 & $4.60 \pm 0.011^{\mathrm{f}, \mathrm{g}}$ & $0.77 \pm 0.008^{\mathrm{f}, g}$ & $36.26 \pm 0.160^{g}$ & $15.8 \pm 0.060^{f, g}$ \\
\hline
\end{tabular}

a,b,c,d,e,f,g Different superscripts letters indicate statistical difference ( $\mathrm{p}<0.05)$.

milk, as reported by Pang, Deeth, Yang, Prakash, and Bansal (2017). The greater viscosity is probably due to the development of a strong network between milk, maltodextrin and the protein present in jumbo squid powder (Brown et al., 2012). According to Lin, Kelly, O’Mahony, and Guinee (2016), the proteins present in food during dairy fermentation contribute strongly to gel formation. It is probable that for all the reasons above, in our study there was a marked difference in viscosity between treatments (Fig. 3). The proteins are sources of nitrogen and it can be fermented due to that some amino acids are glucogenic, and the jumbo squid has glucogenic amino acids (Lopez-Enriquez, OcanoHiguera, Torres-Arreola, Ezquerra-Brauer, \& Marquez-Rios, 2015). These glucogenic amino acids need more energy to convert them to glucose (Lin et al., 2016). Once converting to glucose, the lactic starter culture uses it during the fermentation process. Probably, this explains the reason for network strong formation in yogurt and improving its physical properties.

\subsection{Physicochemical characteristics of yogurt}

The physicochemical properties of the final product - assayed after $24 \mathrm{~h}$ elaboration - were compared (Table 1 ). The lowest $\mathrm{pH}$ value of 4.06 belonged to the YM10 treatment; although, in general, the $\mathrm{pH}$ values of all yogurts were above 4 . This finding falls within the range found by Ramirez-Santiago et al. (2010) and Ozturkoglu-Budak et al. (2016). In this study, an inverse relationship between $\mathrm{pH}$ values and percentages of addition of jumbo squid powder $(\mathrm{p}<0.05)$ was found. The acidity of the yogurt is inversely related to its $\mathrm{pH}$ (Lucey, Van Vliet, Grolle, Geurts, \& Walstra, 1997; Ozturkoglu-Budak et al., 2016; SaintEve et al., 2006). The acidity changed significantly from 0.76 to $1.05 \mathrm{~g} /$ $100 \mathrm{~g}$, increasing with the dose of jumbo squid powder (YM1 to YM10). This final yogurt acidity is normal and very similar for different formulations of yogurt enriched with calcium and other minerals (Santillán-Urquiza et al., 2017). Changes in acidity are mainly the result of the biochemical transformations that occur in fermenting milk during processing and storage (Hashemi-Gahruie et al., 2015). Statistical analysis indicates that there is significant effect of jumbo squid powder on titratable acidity; and this is attributed to the activity of lactic bacteria on the substrate available (Hashemi-Gahruie et al., 2015; Félix-Armenta et al., 2009; Brown et al., 2012).

The viscosities of jumbo squid powder-enriched yogurts were found in the range of 32.71 and 58.90 Pa.s (Table 1) and it was greater than the controls (YM0 and YMMalt3), these values are higher than those reported by Lin et al. (2016) and Ozturkoglu-Budak et al. (2016). However, the viscosity values obtained in this study are within the range earlier observed by Ale et al. (2016) and Cruz et al. (2013), who reported that the viscosity of yogurts added with different kinds of ingredients (i.e., exopolysaccharide, gelatin, and xanthan gum) had high viscosity levels between 10 and 90 Pa.s. Comparable results were also encountered by Pelaes et al. (2015), Pang et al. (2017), OzturkogluBudak et al. (2016), Lin et al. (2016), Brown et al. (2012) and RamirezSantiago et al. (2010) in yogurts enriched with extracts, powdered starches and protein concentrates of dairy origin. The chemical composition of the control yogurt is modified by the presence of more proteins and carbohydrates, which causes structural changes within the gel and increased stiffness in the protein matrix (Pang et al., 2017). Analysis of variance as well as Tukey's test indicated that jumbo squid powder had a significant positive effect $(\mathrm{p}<0.05)$ on the viscosity factor.

Syneresis is widely known to be a detrimental characteristic of yogurt (Lucey et al., 1997). The values of syneresis (1-16.1\%) (Table 1) are below those reported by Ako (2015) for control yogurts (20-40\%), but are considerably lower than those reported by Ale et al. (2016) (70-72\%) and Cruz et al. (2013) (30-36\%) who formulated yogurts with exopolysaccharide and inulin. The yogurts formulated with 7 (YM7) and $10 \mathrm{~g} / 100 \mathrm{~mL}$ (YM10) jumbo squid powder yielded the lowest syneresis; this positive effect on syneresis is a functional property of the protein (Brown et al., 2012; Domagala, Wszolek, Tamime, \& Kupiec-Teahan, 2013). Protein and maltodextrin helps retain water, thus avoiding the defect of syneresis (Cruz et al., 2013; Lin et al., 2016). Dönmez et al. (2017) and Ramirez-Santiago et al. (2010) explained that causes of syneresis in yogurt are the variations in incubation temperature and insufficient cooling during processing; although it is a phenomenon strongly linked to the formulation of yogurt (Pelaes et al., 2015). The two types of yogurt elaborated (with and without jumbo squid powder) have significant differences $(p<0.05)$ in syneresis.

\subsection{Sensory analysis of yogurt}

The sensory tests using the hedonic scale showed that yogurts with lower concentrations of jumbo squid powder were better qualified by the panelists (Fig. 4). The control treatment presented an average acceptability, which was comparable to those reported by RamirezSantiago et al. (2010) and Ale et al. (2016). The treatment YM3 (3 g/

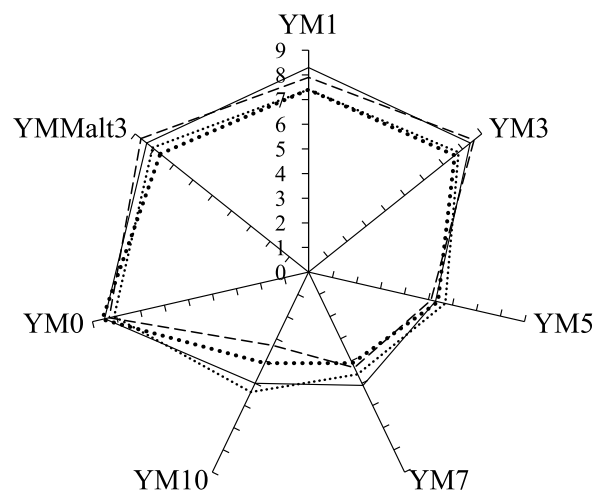

Figure 4. Sensory analysis of the seven yogurts produced with $1 \mathrm{~g} / 100 \mathrm{~mL}$ (YM1), $3 \mathrm{~g} / 100 \mathrm{~mL}$ (YM3), $5 \mathrm{~g} / 100 \mathrm{~mL}$ (YM5), $7 \mathrm{~g} / 100 \mathrm{~mL}$ (YM7), $10 \mathrm{~g} / 100 \mathrm{~mL}$ (YM10), no addition (YM0) of jumbo squid powder, and $3 \mathrm{~g} / 100 \mathrm{~mL}$ (YMMalt3) of maltodextrin. Symbols: - - - - Texture, ......... Color, - Taste and ..... Aroma. 
$100 \mathrm{~mL}$ ) was given taste and aroma scores (7.6 points) that were higher than the other treatments with jumbo squid powder, but it was below the score obtained by the controls (YM0 and YMMalt3). Aroma and characteristic taste of yogurt are produced by several volatile fatty acids which are typical of the ingredients used in its formulation (HashemiGahruie et al., 2015). Also, among the treatments, there were significant differences in color, taste, and texture. The YM3 treatment did not differ statistically ( $\mathrm{p}>0.05$ ) from the controls.

Despite the higher viscosity and lower syneresis of yogurts produced with higher concentrations of jumbo squid powder (YM7, YM10), in terms of organoleptic properties such yogurts were not as sensory qualified as those produced with lower doses of powder (YM1, YM3). While sensory measurements are still subjective, the experience of the panelists has been known to correlate positively with food preference (Lopez-Enriquez et al., 2015; Tahsiri et al., 2017).

\section{Conclusion}

The incorporation of jumbo squid powder had a favorable effect on the physicochemical properties ( $\mathrm{pH}$, acidity, viscosity and syneresis) of yogurt and did not adversely affect its organoleptic properties (taste, aroma, texture, and color). The time required for incubation was $3 \mathrm{~h}$, being considerably shorter than the average time generally used. These results could be of commercial interest for food innovators. Yogurt with $3 \mathrm{~g} / 100 \mathrm{~mL}$ incorporation of jumbo squid powder had the highest acceptability and the scores of its sensorial properties by means of a ninegrade hedonic scale were: taste ( 8.4 points), aroma ( 7.6 points), texture ( 8.6 points) and color ( 7.8 points), which were very similar to those of the control yogurts.

\section{Acknowledgements}

The authors are grateful to Biologist Armando Solari and the Technological Institute of Production (ITP, Peru) for all support provided in the conduction of this research. Dr. Gonzales-Barron wishes to acknowledge the financial support provided by the Portuguese Foundation for Science and Technology (FCT) through the award of a five-year Investigator Fellowship (IF) in the mode of Development Grants (IF/00570).

\section{References}

Ako, K. (2015). Influence of elasticity on the syneresis properties of k-carrageenan gels Carbohydrate Polymers, 115, 408-414.

Alegre, A., Ménard, F., Tafur, R., Espinoza, P., Argüelles, J., Maehara, V., et al. (2014). Comprehensive model of jumbo squid Dosidicus gigas trophic ecology in the northern Humboldt Current system. PLoS One, 9, 1-12.

Ale, E. C., Perezlindo, M. J., Pavón, Y., Peralta, G. H., Costa, S., Sabbag, N., et al. (2016). Technological, rheological and sensory characterizations of a yogurt containing an exopolysaccharide extract from Lactobacillus fermentum Lf2, a new food additive. Food Research International, 90, 259-267.

Alfaro, L., Hayes, D., Boeneke, C., Xu, Z., Bankston, D., Bechtel, P. J., et al. (2015). Physical properties of a frozen yogurt fortified with a nano-emulsion containing purple rice bran oil. LWT - Food Science and Technology, 62, 1184-1191.

AOAC (2005). Official methods of analysis (18th ed.). MD, USA: Association of Official Analytical Chemists.

Arango, O., Trujillo, A. J., \& Castillo, M. (2013). Influence of fat replacement by inulin on rheological properties, kinetics of rennet milk coagulation, and syneresis of milk gels. Journal of Dairy Science, 96, 1984-1996.

Arias-Moscoso, J. L., Maldonado-Arce, A., Rouzaud-Sandez, O., Márquez-Ríos, E., TorresArreola, W., Santacruz-Ortega, H., et al. (2014). Physicochemical characterization of protein hydrolysates produced by autolysis of jumbo squid (Dosidicus gigas) byproducts. Food Biophysics, 10, 145-154.

Arkhipkin, A., Argüelles, J., Shcherbich, Z., \& Yamashiro, C. (2014). Ambient temperature influence adult size and life span in jumbo squid. Dosidicus gigas. Canadian Journal of Fisheries and Aquatic Sciences, 409, 1-37.

Brown, K. M., McManus, W. R., \& McMahon, D. J. (2012). Starch addition in renneted milk gels: Partitioning between curd and whey and effect on curd syneresis and gel microstructure. Journal of Dairy Science, 95, 6871-6881.
Cano-Chauca, M., Stringheta, P. C., Ramos, A. M., \& Cal-Vidal, J. (2005). Effect of the carriers on the microstructure of mango powder obtained by spray drying and its functional characterization. Innovative Food Science \& Emerging Technologies, 6 , 420-428.

Cruz, A. G., Cadena, R. S., Alvaro, M. B. V. B., Sant'Ana, A. S., Oliveira, C. A. F., Faria, J. A. F., et al. (2013). Assessing the use of different chemometric techniques to discriminate low-fat and full-fat yogurts. LWT - Food Science and Technology, 50, 210-214.

Dihort-García, G., Tolano-Villaverde, I. J., Ezquerra-Brauer, J. M., Ocaño-Higuera, V. M., Ramírez de León, J. A., Torres-Arreola, W., et al. (2016). Effects of $\mathrm{pH}$ and sodium chloride on the gelling properties of a protein concentrate obtained from jumbo squid mantle (Dosidicus gigas). International Journal of Food Properties, 19, 314-325.

Domagala, J., Wszolek, M., Tamime, A. Y., \& Kupiec-Teahan, B. (2013). The effect of transglutaminase concentration on the texture, syneresis and microstructure of settype goat's milk yoghurt during the storage period. Small Ruminant Research, 112, 154-161.

Dönmez, Ö., Mogol, B. A., \& Gökmen, V. (2017). Syneresis and rheological behaviors of set yogurt containing green tea and green coffee powders. Journal of Dairy Science, $100,1-7$.

Félix-Armenta, A., Ramirez-Suarez, J. C., Pacheco-Aguilar, R., Díaz-Cinco, M. E., Cumplido-Barbeitia, G., \& Carvallo-Ruiz, G. (2009). Jumbo squid (Dosidicus gigas) mantle muscle gelled-emulsified type product: Formulation, processing and physicochemical characteristics. International Journal of Food Science and Technology, 44, 1517-1524.

Hashemi-Gahruie, H., Eskandari, M. H., Mesbahi, G., \& Hanifpour, M. A. (2015). Scientific and technical aspects of yogurt fortification: A review. Food Science and Human Wellness, 4, 1-8.

Lin, Y., Kelly, A. L., O'Mahony, J. A., \& Guinee, T. P. (2016). Fortification of milk protein content with different dairy protein powders alters its compositional, rennet gelation, heat stability and ethanol stability characteristics. International Dairy Journal, 61, 220-227.

Liu, B., Chen, X., Chen, Y., Tian, S., Li, J., Fang, Z., et al. (2013). Age, maturation, and population structure of the Humboldt squid Dosidicus gigas off the Peruvian exclusive economic zones. Chinese Journal of Oceanology and Limnology, 31, 81-91.

Lopez-Enriquez, R. L., Ocano-Higuera, V. M., Torres-Arreola, W., Ezquerra-Brauer, J. M., \& Marquez-Rios, E. (2015). Chemical and functional characterization of sarcoplasmic Proteins from giant squid (Dosidicus gigas) mantle. Journal of Chemistry, 2015.

Lucey, J. A., Van Vliet, T., Grolle, K., Geurts, T., \& Walstra, P. (1997). Properties of acid casein gels made by acidification with glucono- $\delta$-lactone. 2 . Syneresis, permeability and microstructural properties. International Dairy Journal, 7, 389-397.

Martín-Sánchez, A. M., Navarro, C., Pérez-Álvarez, J. A., \& Kuri, V. (2009). Alternatives for efficient and sustainable production of surimi: A review. Comprehensive Reviews in Food Science and Food Safety, 8, 359-374.

Mimouni, A., Deeth, H. C., Whittaker, A. K., Gidley, M. J., \& Bhandari, B. R. (2009). Rehydration process of milk protein concentrate powder monitored by static light scattering. Food Hydrocolloids, 23, 1958-1965.

Osuna-Ruíz, I., Yepiz-Plascencia, G., Rouzaud-Sández, O., \& Ezquerra-Brauer, J. M. (2010). Aminopeptidase from jumbo squid (Dosidicus gigas) hepatopancreas: Purification, characterization, and casein hydrolysis. International Journal of Food Science and Technology, 45, 387-394.

Ozturkoglu-Budak, S., Akal, C., \& Yetisemiyen, A. (2016). Effect of dried nut fortification on functional, physicochemical, textural, and microbiological properties of yogurt. Journal of Dairy Science, 99, 8511-8523.

Pang, Z., Deeth, H., Yang, H., Prakash, S., \& Bansal, N. (2017). Evaluation of tilapia skin gelatin as a mammalian gelatin replacer in acid milk gels and low-fat stirred yogurt. Journal of Dairy Science, 100, 3436-3447.

Pelaes, A. C., Goto, P. A., Hanai, L. N., Gomes-da-Costa, S. M., de Abreu Filho, B. A., Nakamura, C. V., et al. (2015). Microbiological, functional and rheological properties of low fat yogurt supplemented with Pleurotus ostreatus aqueous extract. LWT - Food Science and Technology, 64, 1028-1035.

Ramirez-Santiago, C., Ramos-Solis, L., Lobato-Calleros, C., Peña-Valdivia, C., VernonCarter, E. J., \& Alvarez-Ramírez, J. (2010). Enrichment of stirred yogurt with soluble dietary fiber from Pachyrhizus erosus L. Urban: Effect on syneresis, microstructure and rheological properties. Journal of Food Engineering, 101, 229-235.

Rocha-Estrada, J. G., Córdova-Murueta, J. H., \& García-Carreño, F. L. (2010). Functional properties of protein from frozen mantle and fin of jumbo squid Dosidicus gigas in function of pH and ionic strength. Food Science and Technology, 16, 451-458.

Saint-Eve, A., Lévy, C., Martin, N., \& Souchon, I. (2006). Influence of proteins on the perception of flavored stirred yogurts. Journal of Dairy Science, 89, 922-933.

Santillán-Urquiza, E., Méndez-Rojas, M.Á., \& Vélez-Ruiz, J. F. (2017). Fortification of yogurt with nano and micro sized calcium, iron and zinc, effect on the physicochemical and rheological properties. LWT - Food Science and Technology, 80, 462-469.

Sant'Anna, V., Christiano, F. D. P., Marczak, L. D. F., Tessaro, I. C., \& Thys, R. C. S. (2014) The effect of the incorporation of grape marc powder in fettuccini pasta properties. LWT - Food Science and Technology, 58, 497-501.

Tahsiri, Z., Niakousari, M., Khoshnoudi-Nia, S., \& Hosseini, S. M. H. (2017). Sensory evaluation of selected formulated milk barberry drinks using the fuzzy approach. Food Science \& Nutrition, 1-11.

Trübenbach, K., da Costa, G., Ribeiro-Silva, C., Ribeiro, R. M., Cordeiro, C., \& Rosa, R. (2014). Hypoxia-driven selective degradation of cellular proteins in jumbo squids during diel migration to the oxygen minimum zones. Marine Biology, 161, 575-584. 